\title{
Sub-Lethal Effect of Four Plant Extracts on Growth And Reproductive Parameters of Culex pipines molestus Forskal (Diptera: Culicidae) *
}

\section{Atallah F. Mekhlif}

Dept. of Biology,

College of Education

Mosul University

atalloahmekhlif@yahoo.com

\section{Mohammad M. AbdulRazzak}

Ministry of Education

Ninevah Directorate

\section{Received \\ $09 / 09 / 2013$ \\ Accepted \\ $06 / 11 / 2013$ \\ التأثير تحت القاتل لمستخلصات أربع نباتات في نمو ومؤشرات \\ Culex pipiens moletus Forskal تكاثر البعوض}

\begin{abstract}
الخلاصة
أجريت هذه الدراسة من اجل نقييم التأثير غير القاتل للمستخلص الايثانولي لأربعة انواع من

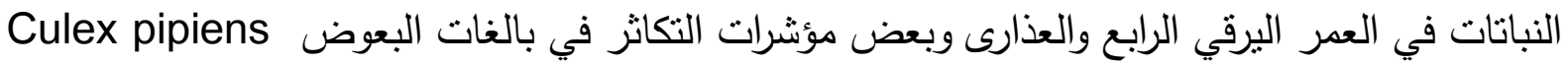
molestus Forskal Carissa grandiflora

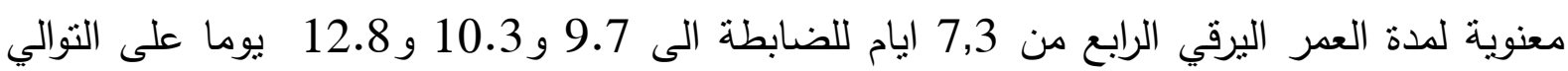
فيما سبب الحنظل Citrullus colocynthis عند نفس التركيز نقصانا واكتمل بمدة 3.4 ايام. وقد التدابع اكتمل طور العذراء وبمدة اطول من المجموعة الضابطة وبشكل معنوي للمستخلصات الاربعة.

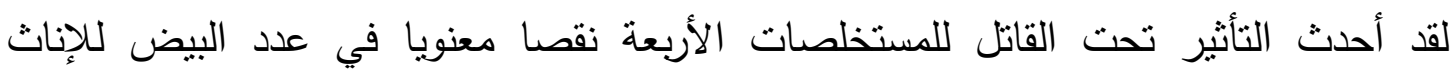

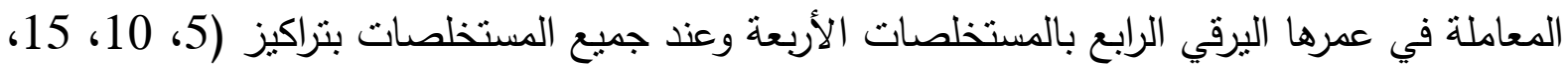
20 ج ف م) المستخدمة. وقد اتبع النقص في عدد البيض نقصا في الخصوبة والانتاجية للإناث، كما

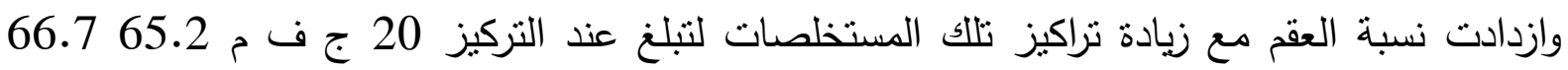
و73.19 و76.5\% لكل من مستخلصات شجرة الجنة والكارسيا والحنظل والسذاب على التوالي.
\end{abstract}




\section{ABSTRACT}

The ethanol extracts of leaves Alianthus altissima, Carrisa grandiflora, fruits of Citrullus colocynthis and aerial parts of Ruta graveolens was tested against fourth instar larvae of the mosquito, Culex pipines molestua Forskal through sublethal doses at the concentrations 5,10,15 and $20 \mathrm{ppm}$. The extracts of $C$. grandiflora, A. altissima and $R$. graveolens were prolonged IV-P time with $9.7,10.3$ and 12.8 days at $20 \mathrm{ppm}$. Whereas, the period shorted to 4.3 days for $C$. colocynthis in comparison with control 7.3 days. All the plant extracts extended pupal period with significant time, but not more 3.1 days, and 2.1 days for untreated pupae. The reproductive parameters as egg laying hatchability, fecunidity, fertility and sterility percent were showed significant values of emerged adults treated with the plant extracts at IV larval instar.

Keywords: Culex pipiens molestus, growth disruption, fecunidity, fertility, sterility .

\section{INTRODUCTION}

Many mosquitoes species are agent vectors of the most threating diseases in tropics and subtropic areas like malaria, yellow fever, dengue fever, encephalitis and west Nile virus ${ }^{[1]}$. Also, mosquitoes transmit diseases among animals like fouwl pox of chicken, meyxomalosis of rabbits, rift valley of sheep and encephalitis of horses. Moreover, their hovering sound cause great discomfort ${ }^{[2]}$.

In Iraq, there were 16 Anopheles spp. and 18 Culex spp. Distributed in all Iraq regions ${ }^{[3]}$. Culex pipiens L. represents mosquito species complex, the principle members of the complex are : pipiens and molestus ${ }^{[4,5]}$. Culex pipiens biotype molestus, the anthropophilic biotype of the Culex pipiens complex ${ }^{[6]}$. Secondary metabolic compounds of plants act as repellent, oviposition or food deterrent, growth inhibitors and significant prolongation of larval and pupal duration ${ }^{[7]}$. Plant bioinsecticides are alternatives to costly organic pesticides and usually safe to non-target organisms ${ }^{[8,9]}$. They are autodegradable and considered one of the safely methods of pests and vectors control ${ }^{[10,11]}$. Application of phytochemicals in mosquitoes control were in use since $1920^{[12]}$.

The objective of the present study was to examine effect of some native and implanted plants on larval and pupal duration of $C$. pipiens molestus and evaluate the effectiveness of some plant extracts against some biological aspects of this adult mosquito. 


\section{MATERIALS AND METHODS \\ Plant extracts}

Leaves of Carissa grandiflora (Eckl.) A. DC (Apocynaceac), fruits of Citrullus colocynthis L. (Cucurbitaceae), leaves of Alianthus altissima L. (Simaroubaceae) and aeriel parts of Ruta graveolens L. (Rutaceas) were collected from the Mosul University park except $C$. colocynthis fruits were getting from the local market. The plant parts were washing and dried in shadow place then powdered with electrical grinder.

Method of the plant powers extractions was modified after Mekhlif ${ }^{[13]}$, as fellows, $150 \mathrm{ml}$ of $96 \%$ ethanolic alcohol was added to $50 \mathrm{gms}$. of each plant sample, the mixture was left for $48 \mathrm{hr}$ for maceration in refrigerator at $4^{\circ} \mathrm{C}$. the mixture was stirred for $24 \mathrm{hr}$. and filtrated through Whatman No.1 filter paper, the solvent was evaporated by lifting exposed to atmosphere over night. The dried extracts were kept in dark and constant $4^{\circ} \mathrm{C}$ until experimental treatment.

The mosquito,Culex pipiens molestus colony was established in the insectarium at Biology Department, Education College, Mosul University, Mosul City. The insectarium was adjusted at $27+2^{\circ} \mathrm{C}$ temperature, $70 \%+5$ relative humidity under 16:8 light and dark photoperiod cycle. The larvae were fed with artificial food (powdered mixture of mouse diet and dried yeast powder in the ratio of $3: 1)^{[14]}$. The molted pupae were transferred to new trays containing tap water and placed in screened cages $(1 \times 1 \times 1 \mathrm{~m})$, where adults emerged. Adult mosquitoes were fed on a $10 \%$ sucrose solution, the three-day starved females fed from fresh blood of pigeon. The egg rafts produced due to adults mating were kept to continue next generation.

\section{Bioassay tests}

The fourth instar larvae of $C$. pipiens molestus were tested with different concentrations $(5,10,15$ and $20 \mathrm{ppm}$.) of selected plant extracts according to the modified $\mathrm{WHO}{ }^{[15]}$. A total of 25 larvae were introduced in $250 \mathrm{ml}$ plastic cups each containing one of the various concentrations of the applied plant extracts, the treatment were replicated three times.

Fecundity, fertility and sterility percentages of the developed adults were calculated as follow :

$$
\text { Fecundity }=\frac{\text { Ova No. of treated female }}{\text { Ova No. of control female }} \times 100^{[16]}
$$

Larvae counted of the treated female

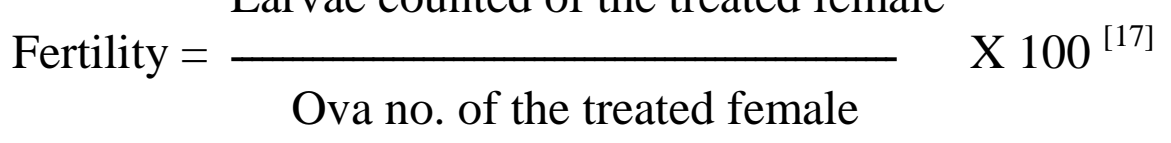


Sterility $=\left[1-\left(\mathrm{F}_{\mathrm{t}} \times \mathrm{F}_{\mathrm{et}} / \mathrm{F}_{\mathrm{c}} \times \mathrm{F}_{\mathrm{ct}}\right)\right] \times 100^{[18]}$

$F_{t}=$ fecundity females treated.

$\mathrm{F}_{\mathrm{et}}=$ fertility females treated.

$\mathrm{F}_{\mathrm{c}}=$ fecundity females control.

$\mathrm{F}_{\mathrm{ct}}=$ fertility females control.

Pupal malformation percent was estimated by any change in color, size, shape or failure to develop to adult stage. Pupal malformation $\%=\mathrm{C} / \mathrm{A} \times 100$, where $\mathrm{C}=$ No. of malformed pupae and $\mathrm{A}=$ number of tested pupae.

\section{RESULTS AND DISCUSSION Effect of the extracts on the life cycle}

Table 1 show significant disruption of fourth larval instar and pupal periods, the disruption in the life cycle ranged between elongation and shortening for those periods. The disruption range depends upon the plant species and its concentration. In comparison with the control period (7.3 days) extracts of $C$. granliflora, A. altessima and $R$. graveolens were extended IVlarval instar period especially $R$. graveolens (12.8 days at $20 \mathrm{ppm}$.). while C. colocynthis shorted this period up to 4.3 days, at $20 \mathrm{ppm}$. In spite of short pupal period ( 2.1 days) of normal pupae, but this stage may extended between 2.5-3.1 days as result of water of the pupae treated with 10,15 and $20 \mathrm{ppm}$. of the plant extracts (Table 1). The active metabolic compound of the extracts were could be behaved as growth regulators as Agonist and antagonist hormones, so that, accelerated the molting hormones or inhibited them through interference with molting hormone receptors. ${ }^{[19,20]}$. This hormonal disturbance would led to either shortening nor extending of one or both larva and pupa duration with significance time, also Table 1 indicated to very notable malformation percent of obtained pupae from treated larvae. These malformations were significantly correlated with increasing of the extracts concentrations at 15 and $20 \mathrm{ppm}$.

As shown from the results of Table 1, the emergence average and emergency percent were affected by the plant extract and its concentration, where the adult emergence reduced to $68.0,54.0,54.0$ and $48.0 \%$ at $20 \mathrm{ppm}$ of $C$. grendiflora, A. altissima, C. colocynthis and $R$. graveolens respectivaly, compared to $100 \%$ of untreated group. The emergence failure of $C$. pipiens molestus adults was mainly related with the proteinaceous eclusion hormone inhibition, due to its denaturation through the extracts applications. 
Table 1: Effect of different plant extracts on some aspects immature mosquito. Culex pipiens molestus reared in media containing different extract concentrations.

\begin{tabular}{|c|c|c|c|c|c|c|}
\hline $\begin{array}{l}\text { Plant species } \\
\text { parts used }\end{array}$ & $\begin{array}{l}\text { Conc } \\
\text { (ppm) }\end{array}$ & $\begin{array}{l}\text { IV-larva } \\
\text { Duration }\end{array}$ & $\begin{array}{l}\text { Pupal** } \\
\text { duration }\end{array}$ & $\begin{array}{l}\text { Malformed } \\
\text { pupae } \%\end{array}$ & $\begin{array}{l}\text { Emergence } \\
\text { average }\end{array}$ & $\begin{array}{l}\text { Emergence } \\
\%\end{array}$ \\
\hline \multirow{4}{*}{$\begin{array}{l}\text { C. } \\
\text { (Leaf) }\end{array}$ grandifloral } & 5 & $* 7.7 \pm 0.6 \mathrm{fg}$ & $2.2 \neq 061$ & 5.2 & $23.7 \pm 0.6 \mathrm{~b}$ & 94.8 \\
\hline & 10 & $8.3 \pm 0.6$ efg & $2.2 \pm 1.5 \mathrm{~h}$ & 12.0 & $22 \pm 1.0 \mathrm{c}$ & 88.0 \\
\hline & 15 & $8.7 \pm 0.6$ def & $2.4 \pm 0.6 \mathrm{f}$ & 21.1 & $19.7 \pm 0.6 \mathrm{e}$ & 78.8 \\
\hline & 20 & $9.7 \pm 0.6 \mathrm{~cd}$ & $2.5 \pm 1.5 \mathrm{e}$ & 32.0 & $17.0 \pm 1.0 \mathrm{hi}$ & 68.0 \\
\hline \multirow{4}{*}{$\begin{array}{l}\text { C. colocynthis } \\
\text { (fruits) }\end{array}$} & 5 & $6.3 \pm 0.6 \mathrm{ih}$ & $2.3 \pm 1.2 \mathrm{~g}$ & 14.8 & $21.3 \pm 0.6 \mathrm{ed}$ & 85.2 \\
\hline & 10 & $5.7 \pm 0.6 \mathrm{i}$ & $2.5 \pm 1.5 \mathrm{~g}$ & 20.0 & $20.0 \pm 1.5 \mathrm{e}$ & 80.0 \\
\hline & 15 & $5.30 .6 \mathrm{ij}$ & $2.7 \pm 0.6 \mathrm{~d}$ & 30.8 & $17.3 \pm 1.2 \mathrm{gh}$ & 69.2 \\
\hline & 20 & $4.3 \pm 0.6 \mathrm{j}$ & $2.9 \pm 1.5 \mathrm{~b}$ & 45.2 & $13.7 \pm 0.6 \mathrm{j}$ & 54.8 \\
\hline \multirow{4}{*}{$\begin{array}{l}\text { A. attissiam } \\
\text { (leaf) }\end{array}$} & 5 & $7.7 \pm 0.6 \mathrm{fg}$ & $2.2 \pm 0.6 \mathrm{~h}$ & 18.8 & $20.3 \pm 0.6 \mathrm{de}$ & 81.2 \\
\hline & 10 & $8.7 \pm 0.6$ def & $2.4 \pm 0.6 \mathrm{fg}$ & 26.8 & $18.3 \pm 0.6 \mathrm{fg}$ & 69.9 \\
\hline & 15 & $9.2 \pm 1.0$ cde & $2.6 \pm 1.2 \mathrm{e}$ & 36.0 & $16.0 \pm 1.0 \mathrm{i}$ & 64.0 \\
\hline & 20 & $10.3 \pm 0.6 \mathrm{c}$ & $2.8 \pm 0.6 \mathrm{c}$ & 41.2 & $14.7 \pm 0.6 \mathrm{j}$ & 58.8 \\
\hline \multirow{4}{*}{$\begin{array}{l}\text { R. graveolens } \\
\text { (Aried parts) }\end{array}$} & 5 & $8.8 \pm 1.0$ def & $2.4 \pm 1.0 \mathrm{fg}$ & 22.8 & $19.3 \pm 0.6$ ef & 77.2 \\
\hline & 10 & $9.8 \pm 0.8 \mathrm{~cd}$ & $2.5 \pm 1.0 \mathrm{e}$ & 32.0 & $17.0 \pm 1.0 \mathrm{hi}$ & 68.0 \\
\hline & 15 & $11.7 \pm 0.6 \mathrm{~b}$ & $2.8 \pm 1.15 \mathrm{c}$ & 41.8 & $14.3 \pm 0.6 \mathrm{j}$ & 57.7 \\
\hline & 20 & $12.8 \pm 0.8 \mathrm{a}$ & $3.1 \pm 1.53 \mathrm{a}$ & 52.0 & $12.0 \pm 1.0 \mathrm{k}$ & 48.0 \\
\hline Control & $\mathbf{0}$ & $7.3 \pm 0.6 \mathrm{gh}$ & $2.12 \pm 1.0 \mathrm{i}$ & 0.0 & $25.0 \pm 0.0 \mathrm{a}$ & 100 \\
\hline
\end{tabular}

* - Different superscripts in the column indicate significance difference at P 0.05 level by Duncan's test.

** - Values are mean \pm SD of 25 immature stages observed

\section{Mosquito reproduction after the treatment :}

Exposure of the 4th instar larvae of the mosquito, C. pipiens molestus to sublethal doses $(5,10,15$ and $20 \mathrm{ppm}$.) of the plant extracts were significantly reduced the mean number of eggs oviposited by obtained females. Table 2 indicated that mean of control was oviposited 227.5 and that number significantly reduced at all the applied concentrations. At $5 \mathrm{ppm}$ treatment, the egg laying of the females decreased with 66, 79, 94 and 101 eggs for A. altissima, C. grandiflora, C. colocynthis and R. graveolens respectively. Also the fertility were slightly reduced at 5 and $10 \mathrm{ppm}$ concentration, but those reductions decreased at $20 \mathrm{ppm}$ from $94.9 \%$ for control to 77.4, 76.7, 67.1 and $61.5 \%$ for A. altissima, C. grandiflora, $C$. colocynthis and $R$. graveolens respectively. Also for the applied concentrations $(5,10,15$ and $20 \mathrm{ppm})$ in table 2 , the sterility percent for the developed adults formerly treated with the extract at the larval stage ranged between 33.4-65.2\% and 37.5-66.7\% for A. altissima and C. grandiflora respectively. On the other hand, extracts of $R$. graveolens and $C$. colococynthis more effective and their sterility percent ranged between 46.5-73.1\% and 50.4-76.5\%. 
Sub-Lethal Effect of Four Plant Extracts on Growth and ....

Table 2 : Efficacy comparison among plant extracts through reproductive parameters of Culex prpiens molestus.

\begin{tabular}{|c|c|c|c|c|c|c|}
\hline $\begin{array}{l}\text { Plant } \\
\text { extract }\end{array}$ & $\begin{array}{l}\text { Conc. } \\
\text { (ppm) }\end{array}$ & $\begin{array}{l}\text { Eggs No.l } \\
\text { Female ** }\end{array}$ & $\begin{array}{l}\text { Larvae No. } \\
\text { Female I }\end{array}$ & $\begin{array}{l}\text { Fecundity } \\
\%\end{array}$ & $\begin{array}{l}\text { Fertility } \\
\%\end{array}$ & $\begin{array}{l}\text { Sterility } \\
\%\end{array}$ \\
\hline \multirow{4}{*}{ Carissa grandifora } & 5 & $* 148.0 \pm 5.6 \mathrm{~b}$ & $135.0 \pm 5.7 \mathrm{~b}$ & 65.1 & 91.2 & 37.5 \\
\hline & 10 & $129.5 \pm 4.0 \mathrm{~cd}$ & $113.0 \pm 4.0 \mathrm{c}$ & 56.9 & 87.3 & 48.2 \\
\hline & 15 & $111.0 \pm 5.6$ efg & $93.0 \pm 5.9$ def & 48.8 & 83.8 & 56.9 \\
\hline & 20 & $94.3 \pm 4.1 \mathrm{hi}$ & $72.3 \pm 4.1 \mathrm{gh}$ & 41.7 & 76.7 & 66.7 \\
\hline \multirow{4}{*}{ Alianthus altissima } & 5 & $159.0 \pm 10.6 \mathrm{~b}$ & $143.8 \pm 10.5 b$ & 69.96 & 90.4 & 33.4 \\
\hline & 10 & $126.8 \pm 7.0$ cde & $\begin{array}{c}108.8 \pm 7.27 \\
\text { cd }\end{array}$ & 55.7 & 85.8 & 49.6 \\
\hline & 15 & $113.5 \pm 5.2$ defg & $93.03 \pm 5.1 \mathrm{def}$ & 49.9 & 82.2 & 56.8 \\
\hline & 20 & $97.3 \pm 6.6 \mathrm{ghi}$ & $75.3 \pm 6.7 \mathrm{~g}$ & 42.7 & 77.4 & 65.2 \\
\hline \multirow{4}{*}{ Citrullus colocynthis } & 5 & $133.0 \pm 5.7 \mathrm{c}$ & $115.5 \pm 5.4 \mathrm{c}$ & 58.5 & 86.8 & 46.5 \\
\hline & 10 & $116.8 \pm 3.7$ cdef & $95.0 \pm 3.7 \mathrm{de}$ & 51.3 & 81.4 & 56.0 \\
\hline & 15 & $102.0 \pm 4.2 \mathrm{fgh}$ & $77.5 \pm 44.8 \mathrm{fg}$ & 44.8 & 75.9 & 64.1 \\
\hline & 20 & $86.5 \pm 3.9$ hi & $58.0 \pm 3.4 \mathrm{hi}$ & 38.5 & 81.2 & 73.1 \\
\hline \multirow{4}{*}{ Ruta graveolens } & 5 & $126.0 \pm 5.5$ cde & $107.0 \pm 5.5 \mathrm{~cd}$ & 56.4 & 84.9 & 50.4 \\
\hline & 10 & $111.2 \pm 2.2 \mathrm{efg}$ & $89.3 \pm 2.2 \mathrm{efg}$ & 48.9 & 80.2 & 58.7 \\
\hline & 15 & $101.3 \pm 3.4 \mathrm{fgh}$ & $75.3 \pm 3.4 \mathrm{~g}$ & 44.5 & 74.3 & 65.1 \\
\hline & 20 & $82.2 \pm 2.1 \mathrm{i}$ & $50.8 \pm 1.7 \mathrm{i}$ & 36.3 & 61.5 & 76.5 \\
\hline Control & $\mathbf{0}$ & $227.5 \pm 21.0$ & $216.0 \pm 22.2 \mathrm{a}$ & 100 & 94.9 & 0.0 \\
\hline
\end{tabular}

$* *$ Values are mean + SD of 6 females

* Means followed by the same letter (vertically) are not significantly different at P 0.05 level by Duncan's test.

\section{CONCLUSION}

The extensive use of chemical pesticides inducing resistance in mosquitoes beside residues contamination of human food and environmental pollution. So the present study was designed to evaluate the sublethal effect of the plant extracts. An insecticide does not need to cause high mortality on target organisms in order to be acceptable. Besides toxic effect of the plant extract their active ingredients has interfering ability with the hormonal system of the insect and causing hormonal disruption, so cause extending of the life cycle, this meaning reducing the generations numbers of $C$. pipiens moloustes as multivolatine insect or reducing the females fecunidity through acceleration of growth and produce sterile or less fertile ones ${ }^{[7,19]}$. Due to gonads of the adult insects were histolysed after larval diet application with plant extracts ${ }^{[21]}$

The sub-lethal effect of the plant extracts contributes the toxic effect of the plant extracts and enhances their eco-friendly roles through sterility and reducing population density. 


\section{REFERENCES}

1. Ghosh, A., Choudhury, N., and Chandra, G. (2012), Plant extracts as potential mosquito larvicides, Indian J. Med. Res., (135), 581-598.

2. Ali, N.O., E.1-Rabaa, F.M.(2010), Larvicidal activity of some plant extracts to larvae of the mosquito Culex quinquefasciatus (Say 1828), Eur. Rev. Med. Pharmacol. Sci., (14), 925-933.

3. Abu Elhab, J.K.,(1979), "Medical and Veterinary insects of Iraq" . Baghdad Univ. Press. pp 450.

4. Olejnicek, J., and Gelbic, I., (2000), Differences in response to temperature and density between two strains of the mosquito Culex pipiens molestus Forskal, J. Vect. Ecol., (25), 136-145.

5. Michaelakis, A., Mihoce, A.P., Kilspoulos, G., Couladoures, E.A., (2007), Attract and kill strategy study on hatched larvae of Culex pipiens, Pest

Manag. Sci., (63), 954-959.

6. Michaelakis, A., Strongilosi, A.T., Bouzas, E.A., Koliopoulos, E.A., (2009), Larvicidal derivatives against the West Nile virus vector Culex pipiens,

Parisitol. Res., (104), 657-662.

7. Mekhlif, A.F., (2007), Efficacy of enriched Melia azedarach L. extract on immature stages of the pest Spodoptera cilium latebrosa (Guerine)(Lepdoptera: Noctuidae), Tikrit J. Pharmecut. Sci., (3), (1), 63-68.

8. Ezeonu, F.C., Chidume, G.I., kUdesdl, S.C., (2001), Insecticidal properties of volatile exocarpe and orage peels, Bioresour. Technol., (76), 273-274.

9. Khater, H. F., and Shalaby, A.A., (2008), Potential of biological active plant oils to control mosquito larvae (Culex pipiens,Diptera: Culicidae) from Egyptian locality, Rev. Inst. Med. Trop. S. Paulo, (50), (2), 107-112.

10. Sun,L., Dong, H., and Gvo, C. J., (2006), Larvicidal activity of extracts of Ginkgo bilobe exocarpe for three strains of Culex pipiens Pallens, Med. Entomol., (43), 258-261.

11. Al-Mekhlafi, F.A., Abu Taha, N., Mashaly, M.A., and Wodan, M.A., (2013), Larvicidal activity of selected xerophytic plants against Culex pipiens and Aedescaspruse, Pakistan J. Zool., (45), (1), 241-246.

12. Roack, RC., (1947), Some promising insecticidal plants, Econ. Bot., (1), 160-170.

13. Mekhlif, A.F.(2012), Bioefficacy of four botanical extracts against Culex pipiens stages and non-targeted Cironomous ninevah Ahmad (Chironomidae), Rafidain J. Sci., 23(2): 23-35. 14. Marcard, V., Zebitz, C.P., and Schmutterer, M. (1986), The effect of crude methanolic extracts of ajuga spp. On post embryonic development of different mosquito species, J.Appl. Ent., (101), 146154.

14. 15. World Health Organization (WHO), (2005), Guidelines for laboratory and field testing of mosquito larvicides, WHO/CDs/WHOPES/GCD,

$\mathrm{PP} / 2005.1-13$. 
16. Schmidt G.H., Ahmed, A.I. and Breuer,M., (1997), Effect of Melia azedarach extract on larval development and reproduction parameters of Spodoptera littoralis (Boisd) and Agrotis ipsilon (Hufn) (Lep: Noctuidae ), Anz.Schadinskde, Pelonzenchutz, Umweltschutze, (70), 4-12.

17. Szentest, A., (1972), Studies on the mass rearing of Acantho scellides obtectus Say (Coleoptera: Bruchidae), Acta phytopathologia Acadmic Scientiarum Hungoricac, (7), (4), 433- 463.

18. Toppozada, A., Abdallah, S.and Eldefrawi, M.E., (1966), Chemosterilization of larvae and adults of the Egyptian cotton leafworm Prodenia litura, by Aholate, metapa, and tepa, Journal of Economic

Entomology, (59), 1125- 1128.

19. Klowden, M.J., (2007), "Physiological Systems in Insects", Elsevier Inc., pp. 699.

20. Zayed, A.A., Saeed, R.M., El-Namaky, A.H., Ismail, H.M., and Mady,

H.Y., (2009), Influence of Allium sativum and Citrus limon oil extracts and Bacillus thuringiensis on some biological aspects of Culix pipiens larvae (Diptera:Culicidae), World J. Zool., (4), (2), 109-121.

21. Mekhlif, A.F.,(2009), Sub-lethal effect of Melia azedarach L. fruits extracts on gonads of beet armyworm, Spodoptera exigua (Noctuidae: Lepidoptera), J. Anbar Univ., (3), (2), 31-38. 